\title{
Paideusis
}

\section{What Can We Learn from How Socrates Dominates Thrasymachus in Plato's Republic?}

\section{Elizabeth Meadows}

Volume 15, Number 1, 2006

URI: https://id.erudit.org/iderudit/1072696ar

DOI: https://doi.org/10.7202/1072696ar

See table of contents

Publisher(s)

Canadian Philosophy of Education Society

ISSN

0838-4517 (print)

1916-0348 (digital)

Explore this journal

Cite this article

Meadows, E. (2006). What Can We Learn from How Socrates Dominates Thrasymachus in Plato's Republic? Paideusis, 15(1), 87-94.

https://doi.org/10.7202/1072696ar
Article abstract

In this paper I will show how Socrates dominated Thrasymachus by failing to create a relationship with Thrasymachus in which meaningful learning could occur. Although this is a negative example of how a teacher did not help a student learn, from it I believe that we can learn the importance of creating relationships with our students to help them learn and thereby modeling for them how to create such relationships with their students. Listening to, respecting, and responding to our students as they are, to their questions, and to their motivations to learn or not to learn are essential ways for us to help them learn what they and we believe is important for living fulfilling lives. This is justice in teaching.
This document is protected by copyright law. Use of the services of Erudit (including reproduction) is subject to its terms and conditions, which can be viewed online.

https://apropos.erudit.org/en/users/policy-on-use/ 


\title{
What Can We Learn from How Socrates Dominates Thrasymachus in Plato's Republic?
}

\author{
ELIZABETH MEADOWS
}

Roosevelt University

In this paper I will show how Socrates dominated Thrasymachus by failing to create a relationship with Thrasymachus in which meaningful learning could occur. Although this is a negative example of how a teacher did not help a student learn, from it I believe that we can learn the importance of creating relationships with our students to help them learn and thereby modeling for them how to create such relationships with their students. Listening to, respecting, and responding to our students as they are, to their questions, and to their motivations to learn or not to learn are essential ways for us to belp them learn what they and we believe is important for living fulfilling lives. This is justice in teaching.

\section{Introduction}

In recent years, my education students have reminded me about how dominating and infuriating Socrates can be as a teacher. They are so turned off by him in Book 1 of Plato's Republic that they cannot believe that his vision of a just society is truly just. Instead, they perceive it as exploitative of workers, the disabled, and women for the gain of the Philosopher Kings. (They may be right. This would need to be the subject of another paper of this length or longer.) Twenty years ago, I felt deeply angered by Socrates' approach as a freshman at St. John's College, reading Plato for the first time. Since then, I have used Socratic discussions extensively in my teaching and learning and have prided myself on doing so. This method seemed the best to me in its openness to students' thoughts and in its ways of encouraging students to question themselves. I still think that it has great merit. However, spurred on by my students, I now return to my initial, serious questioning of Socrates' behavior and ask what we, as teachers of prospective teachers, can learn from how he dominates Thrasymachus.

Before going further, it is important to state two disclaimers. First, throughout this paper, I am discussing the image of Socrates that Plato presents in the Republic, making no claims as to how close this image is to the actual, historical person of Socrates. There is ample debate over this question that this paper does not enter. Rather, I work with the image of Socrates that Plato presents in this later work in asking my question: what can we learn from how he treats his student, Thrasymachus? This leads to my second disclaimer. Although some argue that the Republic was not written as a consideration of teaching and learning but, rather, as an inquiry into what justice is, this paper explores how this dialogue can still be fruitfully viewed from an educational perspective.

(C) Copyright 2006. The author, Elizabeth Meadows, assigns to Paideusis the right of first publication and educational and nonprofit institutions a non-exclusive license to use this document for personal use and in courses of instruction provided that the article is used in full and this copyright statement is reproduced. Any other usage is probibited without the express permission of the author. 


\section{Thrasymachus Believes that Socrates Dominates Him, and I Agree.}

When Thrasymachus first tells Socrates that justice is "the advantage of the stronger (Plato 1991, 338c)," Socrates responds that, according to this argument, everyone should eat beef if this is what is good for the strongest wrestler. Thrasymachus bursts out, "You are disgusting, Socrates. You take hold of the argument in the way you can work it the most harm (Plato 1991, 338d)." When Socrates restates Thrasymachus' position erroneously — that justice is what the rulers state to be in their best interests even when they make mistakes, Thrasymachus angrily accuses Socrates of being a "bully in discussions (Plato 1993, 340c-d)" who makes "premeditated attempts to wrong him.... [with his] unscrupulous tactics (Plato 1993, 341a-b)." Thrasymachus responds by stating his position even more clearly -that rulers who are true rulers never make mistakes about what is in their best interests and that what is in the best interests of rulers is to take advantage of those weaker than they. Thrasymachus reaffirms that this is justice. Furthermore, Thrasymachus claims that Socrates wants "to use the argument to batter him down (Plato 1993, 341b)." Throughout, Thrasymachus feels that Socrates is trying to beat him down, to refute his argument in a way that does not feel educative or supportive of Thrasymachus' learning something new. After continuing to try to put forth his view, Thrasymachus seems to start to give in to Socrates without really agreeing with him. After Socrates runs Thrasymachus through a logical argument that leads to an inconsistency in Thrasymachus' claim, Thrasymachus says, "but even what you're saying now doesn't satisfy me, and I have something to say about it. But, if I should try to speak, I know well that you would say that I am making a public harangue. So then, either let me speak as much as I want; or, if you want to keep on questioning, go ahead...and...I shall say to you, 'All right,' and ...nod and shake my head (Plato 1991, 350e)." When Socrates asks if Thrasymachus will nod his ahead "contrary to your own opinion," Thrasymachus says he will, and Socrates agrees to let him (Ibid.). Thrasymachus has learned from his interactions with Socrates so far that Socrates will not let him fully speak his mind, that Socrates in some ways wants Thrasymachus to pretend to agree with him, and so Thrasymachus feels silenced about expressing his own thoughts. He explains that he will pretend to agree with Socrates, that he will not be sincerely engaged in this conversation, and that he will not answer honestly.

I agree with Thrasymachus that Socrates has dominated him. Perhaps, when Socrates presents an absurd implication of his arguments about justice being what is advantageous for the stronger, he is trying to help Thrasymachus enter a state of productive confusion in which he will discover that he does not know what he thinks he does, and then want to learn about what he does not know. [Socrates is successful in helping others learn through this process of the elenchus, according to Robert Beck and others.] However, Thrasymachus does not become confused at all. Instead, he argues even more forcefully that he means that justice is what rulers say is in their best interests, and not what is in the best interests of their subjects (Plato 1993, 341a). There is no perplexity in Thrasymachus here and no search for a different way of thinking about justice than what he currently holds. Furthermore, it seems that Socrates has put Thrasymachus on the defensive about his argument and that this state of mind keeps Thrasymachus from being able to reflect upon the substance of what Socrates is saying. Socrates does not help Thrasymachus consider if this is what he would want justice to mean. By the end of their interaction, Socrates has not helped Thrasymachus reflect upon his own thinking in ways that make him seriously consider any other possibility than the one he believes so strongly. In this exchange, Socrates engages Thrasymachus in a polarized argument and not in an exploratory investigation through which Thrasymachus could learn. 


\section{Other Authors Disagree, and I Respond.}

Other authors claim that Socrates' method is not only not dominating of his students, but "positive," according to Bruce Aune (Aune 1997, 302,), and "among the greatest achievements of humanity," according to Gregory Vlastos (Vlastos 1971, 20.) Although I can agree with these descriptions in other interactions in this and other Platonic dialogues, with regard to Socrates' interactions with Thrasymachus, I disagree.

Aune argues that Socrates' "constructive arguments with Thrasymachus (Aune 1997, 302)" comprise much more of their interaction than the "destructive (Aune 1997, 298-99)" refutation of Thrasymachus' arguments. Aune seems to be saying that Socrates refutes Thrasymachus by building up, or constructing, an alternate model of what justice can mean more than by showing the inconsistencies in Thrasymachus' argument. However, Aune admits that Socrates does "extract admissions" from Thrasymachus, "drawing consequences from other admissions that are inconsistent with Thrasymachus" ideas about justice" and "proceeds in a generally elenctic way and achieves his negative result" that Thrasymachus is wrong (Aune 1997, 298-99). Still, Aune claims that Socrates does not, for the most part, achieve this refutation of Thrasymachus through the use of an "essentially...critical, destructive method (Aune 1997, 292)."

I disagree that Socrates is not being destructive in Thrasymachus' experience of the interaction. Aune convinces the reader that Socrates comes up with alternate views to his claims, but Aune ignores the effect that Socrates' behavior has on the person of Thrasymachus, who seems very negatively affected. He calls Socrates "disgusting (Plato 1991, 338d)," and claims that he has planned ahead how he can do Thrasymachus' argument the most harm. Finally, after his brief appearance in Book 1, Thrasymachus leaves the dialogue, never to return. Thrasymachus has been turned off to this subject of justice and perhaps to learning in general. Given that both he and Socrates claim that this inquiry is of the utmost importance in leading a happy life, what could be more destructive than mistakenly believing that to be just means to take advantage of others weaker than oneself? Thrasymachus is left unhappy and with no apparent motive to want to seek for anything different. Daniel Pekarsky seems to agree with me when he claims that Socrates has humiliated Thrasymachus (Pekarsky 1994, 127) and that some will retreat from Socratic teaching into silence. Richard Robinson also seems to concur, writing, "...the reduction to contradiction was so common as to lead to abuse (Robinson 1971, 102)."

On the other hand, Vlastos disagrees, claiming that the Socratic method is "among the greatest achievements of humanity...Because it makes moral inquiry a common human enterprise, open to every man (Vlastos 1971, 20)." Vlastos claims that all one needs is "common sense and common speech (Ibid.)" to inquire with Socrates into moral matters of utmost importance to how one should live one's life. I disagree that Socrates has made such inquiry available to all, because he does not succeed in helping Thrasymachus want to know more than he thinks he already does about justice. He does not seem to share the "common (Ibid.)" speech and sense that Vlastos claims Socrates requires of people. Vlastos seems to imply that this gap is Thrasymachus' responsibility to fill in and not Socrates' when he writes, "Socrates expects you to say what you really believe about the way man should live...about the way you should live (Ibid.)." I disagree: a teacher needs to accept what a student brings or does not bring in terms of life experiences, perspectives, and motives to learn or not to learn and to then work with these in order to help a student learn.

What if a student shows no motive to learn, as with Thrasymachus and his own ideas about what justice means? It is vital that a teacher knows this. Then, instead of running Thrasymachus over with and through abstract arguments to prove him wrong, Socrates could have asked Thrasymachus how he would have liked justice to be, and listened. If Thrasymachus sat silent, Socrates could have joined him. Perhaps Thrasymachus had never before thought that there could be another realm besides the corrupt world he lived in where justice meant abusing others for one's own gain. That realization in itself would go far in helping him want to learn more, I believe. 


\section{What Could Socrates Have Done Differently to Help Thrasymachus Learn?}

If Socrates had asked himself why he felt "scared stiff (Plato 1993, 336d)" when Thrasymachus first enters the dialogue, I think that Socrates could have learned something about himself that could potentially have helped him become a better teacher. Why is Socrates afraid? I have felt afraid when a student asked me a direct question that challenged or contradicted my own thinking. I felt almost frozen, on the spot, and at a loss for how to respond, when a response was being vehemently asked of me. Perhaps Socrates feels stunned and at a loss as well. It seems plausible that Socrates is feeling defensive in the face of what he perceives as an attack by Thrasymachus and becomes dominating as a defense. I think that if Socrates had noticed his desire to defend himself he could have ignored this motive, not acted on it, and, instead, asked himself what would have benefited Thrasymachus most. Socrates is, after all, discussing justice, and it would seem just, I believe, for a teacher to be concerned with helping his student learn, particularly in this case, when the lesson is "what is justice?" By finding out what Thrasymachus is feeling and thinking, I believe that Socrates could have helped Thrasymachus learn. If Socrates had asked Thrasymachus why he was so upset about the way Socrates has been inquiring and not giving his own opinion about what justice is, he might have learned that Thrasymachus could not stand this mode of inquiry and that he was not learning anything meaningful. And, as a teacher, Socrates could then have asked him how he wanted to proceed. If Thrasymachus wanted Socrates to give his opinion, Socrates could have offered it and then listened to his student's response.

Instead, Socrates criticizes Thrasymachus for asking for an answer but restricting which answers are acceptable (Plato 1993, 337b). Socrates avoids directly interacting with the person, Thrasymachus, who is extremely angry at his teacher. Socrates does not want to know how angry Thrasymachus is at him. I think that, as a teacher, Socrates could have helped Thrasymachus learn much more about himself and about justice if he had truly engaged with Thrasymachus' anger. If Socrates had asked him, "You seem very upset, and it seems I have done something to upset you--is it my way of asking question after question and not giving my own answer?" If Thrasymachus had agreed or clarified what was making him so mad, Socrates could have asked, "What can I do to help you learn better?" and then, listened and acted accordingly. Thrasymachus is strongly engaged in the subject at this point in the dialogue, and Socrates could have acknowledged and encouraged his motivation to inquire into the nature of justice instead of shutting Thrasymachus down.

If Socrates had asked Thrasymachus why he believed what he believed instead of questioning him in ways that led to absurdities, he could have learned something about Thrasymachus' life experience that could have helped Socrates relate better to him and thus teach him better. Does Thrasymachus believe that "the just is nothing other than the advantage of the stronger (Plato 1991, 338c)" and that those in power who selfishly take advantage of those they rule are truly just because this is how the world he lives in works? If so, Socrates could have accepted his student's experiences as valid and asked if this is how he would want the world to be. Socrates could have asked if Thrasymachus wanted to learn about another, possible realm of justice. Instead, Socrates talks about ideals while Thrasymachus talks about what is real and the teacher never truly connects with his student. A.G.N. Flew agrees when he writes, "Thrasymachus appeals to his own excessively hard-bitten view of how things actually are, whereas Socrates rests a large part of his case upon claims... about....what ought to be...(Flew 1995, 437)." It seems quite possible that Socrates fails in his ideal of persuading Thrasymachus of what justice really is because he does not help Thrasymachus connect with his own ideals for how the world should be in order to be just. Instead, Socrates fails to understand that each is arguing from different realities. And, so, Thrasymachus seems to feel the need to argue his points over and over again and, finally, to give up and to give in to Socrates without ever reflecting upon his own beliefs or realizing that he might have ideals different from the reality he sees all around. When a teacher fails to take her student's ideas seriously or unendingly refutes the thinking of her student, this student may try to persuade her, but if there is no response, the student will very 
likely give up. Socrates seems so intent upon disproving Thrasymachus in order to prove his own thesis that he never really listens to him and so he does not connect with him as a person.

Given Thrasymachus' strong feelings and certainty that justice is when the powerful abuse the weak for their own gain, Socrates could have asked him if he had ever personally felt harmed by someone with more power. Socrates might have learned that Thrasymachus really did feel harmed by him in this very interaction. He feels that Socrates uses his ideas in a destructive way-to make Thrasymachus look stupid. Although Socrates does deny having planned to harm his student, as Thrasymachus accuses him of doing, he never acknowledges that Thrasymachus feels harmed. Had Socrates wanted to know, he could have discovered that he has hurt Thrasymachus. He could have learned from and with his student how to try to avoid hurting him again. By acknowledging his mistake and affirming his ideals to do no harm, which mirror Socrates' definition of justice (Plato 1993, 335d), Socrates would have begun creating a caring relationship with Thrasymachus within which meaningful learning could occur. Socrates may also have reexamined his teaching practice as it related to his ideals of justice. That is, if Socrates was harming his student, he could have seen that this is not a just way of teaching and then worked to close the gap between his ideals and his teaching practice. The teacher could have learned something very important from his experiences with his student.

The belief that a teacher needs to attend to and take seriously a student's feelings by asking what $\mathrm{s} /$ he can do to help the student learn better may seem a modern view of teaching as contrasted with a perhaps more traditional or even Socratic view of a teacher as teaching knowledge and truth. Perhaps in modern times we tend to think of the teacher as teaching the student, and in Socrates' time, the teacher as teaching the ideas. Some may ask if we have lost a necessary emphasis on knowledge and truth in our contemporary view of teaching. Furthermore, what is it that we moderns are trying to teach?

Unless we are concerned with whom we are trying to teach, we are not likely to be successful in teaching our student(s) the knowledge that we care so much that they do learn. If Socrates had concerned himself with the experiences that Thrasymachus has had that make him so hard-bitten when it comes to his understanding of justice, then he could have a place to begin from in helping to broaden Thrasymachus' views about what Socrates believes justice truly is. Thrasymachus may seem a particularly stubborn case, but it seems true from my experience with this dialogue and of learning and teaching situations in general, that unless a teacher meets a student on his or her own ground of understanding and life experiences, s/he will likely not be successful in leading that student into a broader and perhaps truer understanding of something as important as what makes a person or a city just. With other less outspoken students than Thrasymachus a teacher may have to work hard to find out that the student has not learned. An agreeable attitude and quiet demeanor may mask a student's feeling that the teacher has not connected with her or him to help her learn anything meaningful.

Socrates seems to care a great deal about inquiring into what justice is-he believes that this is an essential question to ask and to live by in order to lead a good and happy life. However, Socrates does not succeed in helping Thrasymachus change his mind at all in the course of his interactions with him. In fact, Socrates seems to make Thrasymachus more determined to hold fast to his mistaken, and what Socrates considers self-damaging, views. If Socrates had cared more for the individual person of Thrasymachus by valuing his ideas and by taking his perspectives on what justice means seriously, then Socrates may have helped him see the error in his beliefs. Socrates may have succeeded in his own goal of helping Thrasymachus see how wrong it is to believe that justice occurs when the stronger harms the weak for the stronger's gain, if Socrates had used his greater knowledge about justice to attend to the feelings and life experiences of his student. In this way, Socrates might have taught Thrasymachus the truth and knowledge that Socrates believed was so important for him to learn. Teaching the student is the best way, I believe, to bring forth the knowledge and ways of thinking that we believe are so important to teach. Furthermore, how we teach our students makes as much of an impact or more as what we teach them: our ways of teaching are an important part of what our students learn from us. 


\section{Implications for the Teaching of Prospective Teachers}

What can we as university teachers of prospective teachers learn from how Socrates treats Thrasymachus? It may be argued that Socrates is simply not concerned with learning how to become a better teacher through learning how his students feel and that he is solely concerned about learning about justice. That may be. Even so, I submit that the reader of this dialogue can learn about issues of teaching and learning through seeing how Thrasymachus feels and responds to Socrates' interactions with him here. This provides an opportunity to reflect upon what it is we are trying to teach today and how we can best succeed at teaching it.

We can learn that in order for our students to learn anything meaningful, we must create caring relationships in which our students feel safe to speak their minds. We can do this by sincerely listening to them, respecting their thoughts, feelings, and motives, and showing them that we truly want to know them. To involve them in this learning relationship, we can constantly welcome and seriously consider their suggestions for how this relationship can be improved.

Our students need to feel safe to speak their minds without fear of being judged negatively by us. This feeling of safety requires that we as teachers listen intently to what our students say, care about how they feel, and validate their thoughts and feelings in a respectful and sincere manner. We need to understand and acknowledge our students in order to help them learn and to help them want to learn. Our students need to feel that we care about knowing their feelings, ideas, and motivations.

It is very possible and probable that we will at times leave our students feeling as if we do not care about what they say. For me, this has happened when I felt very strongly about helping my students to become more tolerant towards people of different sexual orientations. I argued my opinion in the face of what I considered to be their intolerant comments. This left them feeling that they could no longer speak their minds. Once I knew this, through a written note from one student, I asked them what I could do to help them feel safer. I explained my life experiences of having a gay brother who experienced terrible oppression, and my students seemed to understand me better. I told them that my ideals were to have everyone speak their minds honestly and respectfully and that I really appreciated their feedback. We worked together to try to reach these ideals, and their experience of the course seemed to change as they grew more expressive and listened more intently to one another. They seemed more open to learning about issues of sexual orientation in order to become more knowledgeable about and tolerant toward people of differing sexual orientations.

A Muslim student who had at first seemed offended about discussing these issues in class explained later that, in her faith, issues of any kind relating to sexuality are considered deeply private and no one speaks about them publicly. Yet, this student expressed how she had been the victim of oppression in the U.S. because of her religion and cultural background, and that she felt passionately about not perpetuating prejudice toward anyone. She said that she was committed to creating a classroom free of taunting or overt prejudices of any kind, despite her beliefs that homosexuality was wrong. Likewise, a student from a fundamentalist Christian background said that she believed homosexuality was a sin, but that she wanted to educate all of her students well. She seemed to know that she could not do this if she allowed any prejudice to be enacted in any way in her classroom. She asked how teachers can teach that homosexuality is okay when they believe otherwise. Someone asked if this was similar to the question of how to teach about the Republican Party and its positive aspects if one is a staunch Democrat.

In this example, I want to show how the class members opened up to me and to one another about their innermost beliefs and feelings while asking essential questions about how to enact their commitment to educate all of their students well in a safe and tolerant classroom. Through this process in our class together they practiced being open-minded to beliefs and ideas that they did not agree with and which sometimes offended them deeply. This process, I believe, will help prepare them to see the value in being tolerant of differences and the value in helping their students do the same in their future K-12 classrooms. Furthermore, it seems plausible that my students would want to recreate their 
experiences of being valued, respected, and listened to by their teacher in their relationships with one another and with their students.

It may be argued that this example of Socrates' teaching is a good example of failed teaching, and so one cannot make claims about what might have happened with Thrasymachus had Socrates acted differently. I agree that this is a hypothetical argument. But, based on the above example of my own teaching and similar experiences of teaching and learning, I believe that the following are essential ways for us to be as teachers to help our students learn what we believe is so important for them to learn.

We need to ask if our students want to learn what we think they should. If not, why not? Is there a way that we are being as teachers that is turning them away from a topic about which they really do care? If so, we can ask them what is bothering them and work with them to make the relationship better for their learning. Perhaps they think the questions we are asking them to inquire into are irrelevant to their lives. If so, we need to find out what they do want to learn about and what their reasons are for wanting to know these things. And by knowing more about our students, we as teachers can help them learn about issues that they may have never before considered or issues that they find almost taboo, as some of my students felt about issues of sexual orientation. Once we have built a foundation of respect and caring towards our students, in my experience, they open up to what we as teachers have to offer them.

\section{Conclusion}

In conclusion, I believe I have shown how Socrates dominated Thrasymachus by failing to create a relationship with Thrasymachus in which meaningful learning could occur. Although this is a negative example of how a teacher did not help a student learn, from it I believe that we can learn the importance of creating relationships with our students to help them learn and thereby modeling for them how to create such relationships with their students. Listening to, respecting, and responding to our students as they are, to their questions, and to their motivations to learn or not to learn are essential ways for us to help them learn what they and we believe is important for living fulfilling lives. This is justice in teaching.

\section{References}

Aune, Bruce. 1997. The Unity of Plato's Republic. Ancient Philosophy, 17(2): 291-308.

Beck, Robert H. 1985. Plato's Views on Teaching. Educational Theory, 35 (2): 119-135.

Flew, A. G. N. 1995. Responding to Plato's Thrasymachus. Philosophy, 70: 437.

Pekarsky, Daniel. 1994. Socratic Teaching: A Critical Assessment. Journal of Moral Education, 23(2): 119136.

Plato, 1993. Republic. Robin Waterfield, translator. Oxford: Oxford University Press.

Plato, 1991. The Republic of Plato. Allan Bloom, translator. United States of America: Basic Books.

Robinson, Richard. 1971. Elenchus: Direct and Indirect. The Philosopby of Socrates, Anchor Books, New York.

Vlastos, Gregory. 1971. The Paradox of Socrates. The Philosophy of Socrates, Anchor Books, New York.

\section{About the Author}

Elizabeth Meadows is Assistant Professor of Elementary Education at Roosevelt University in Chicago and Schaumburg, Illinois. She enjoys supporting teachers' development by teaching undergraduate 
courses such as "Teaching Social Studies in the Elementary School" and graduate courses such as "Methods of Inquiry in the Classroom." Her current research interests include examining K-12 teachers' responses to faculty study groups on John Dewey's ideas about art, experience and education, and exploring how the teacher-student relationship can help students learn optimally in school. Meadows is Consulting Editor for the new journal, Illinois Child Welfare, whose mission is to improve child welfare services by publishing articles for practitioners, program managers, and policy makers that provide stimulating, relevant knowledge that honors the diversity of cultures and perspectives that constitute child welfare. 